\title{
Efektivitas Konseling Behavioral dengan Teknik Modeling untuk Mengatasi Perilaku Agresif pada Peserta Didik SMP Negeri 07 Bandar Lampung
}

\author{
Rika Damayanti, Tri Aeni
}

\author{
Dosen dan Mahasiswa Fakultas Tarbiyah dan Keguruan, IAIN Raden Intan Lampung
}

Diterima: April 2016. Disetujui: Mei 2016. Dipublikasikan: Juni 2016

\begin{abstract}
Abstrak: Tujuan dari penelitian ini adalah untuk mengetahui menurunya perilaku agresif peserta didik dengan konseling behavioral dengan teknik modeling. Metode penelitianyang digunakan adalah kuantitatif dengan metode design one group pretes-postes. Sampel yang digunakan penelitian ini adalah sebanyak 10 peserta didik dengan melihat kriteria dari perilaku agresif peserta didik. Teknik pengumpulan data menggunakan angket, observasi, wawancara, dan dokumentasi sebagai data pendukung. Hasil penelitian didapatkan adanya penurunan perilaku agresif setelah mengikut konseling behavior dengan teknik modeling.
\end{abstract}

Kata Kunci: Konseling Behavioral, Modeling

\section{Pendahuluan}

Peserta didik merupakan individu yang memiliki karakteristik yang berbeda- beda dalam proses perkembangan memerlukan bantuan dalam mengenal jati diri terutama dilingkungan sekolah dan masyarakat. Peserta didik yang memiliki perilaku agresif diduga dapat menghambat pembentukan kepribadian dan aktualisasi diri dalam kehidupan, terutama dalam meraih prestasi di sekolah dan dikhawatirkan dapat menimbulkan masalah-masalah lain yang lebih kompleks lagi. Hal ini adapun faktor penyebab terjadinya perilaku agresif pada manusia yaitu sosial, personal, kebudayaan, situasional, sumber daya, dan media massa. (Sarlito, 2009). Sementara Menurut Faturochman, bahwa faktor yang memengaruhi agresif yaitu "provokasi, kondisi aversif, isyarat agresif, kehadiran orang lain, dan karakteristik individu. (Sarlito, 2009) Senada dengan pendapat diatas Fuad Nashori mengemukakan faktor terjadinya agresif adalah amarah akibat dari serangan atau gangguan yang dilakukan orang lain, dan frustasi”. (Nashori, 2008)

Bahwa perilaku agresif seringkali dipakai manusia sebagai jalan untuk mengungkapkan perasaan dan menyelesaikan persoalan hidup mereka seperti untuk mencelakakan orang lain secara tidak langsung, peperangan, perkelahian antar pelajar, dan lain sebagainya. Akhir-akhir ini bertebaranperistiwa-peristiwa agresif yang bersifat massal.

Berdasarkan fenomena data awal yang diperoleh dari hasil sharing bersama guru bimbingan dan konseling di Bandar Lampung, diketahui bahwa peserta didik SMPN 7 Bandar Lampung mengalami masalah perilaku agresif. Masalah perilaku agresif ini ditunjukan kepada peserta didik misalnya, berkelahi, mengganggu, melakukan perilaku agresif secara verbal misalnya, memaki-maki orang lain, mengejek, melawan terhadap guru dan menyebar gosip tentang orang lain. Maka perilaku tersebut adalah bentuk perilaku agresif.

Fenomena perilaku agresif juga terjadi di SMPN 7 Bandar Lampung, ketika peneliti mengamati langsung selama melaksanakan (PPL) di SMPN 7 Bandar Lampung di sekolah tersebut. SMPN 7 Bandar Lampung merupakan salah satu Sekolah Menengah Pertama yang ada di Jl. Sultan Badarudin, No. 4 desa Gunung Agung, kecamatan Langka Pura, kabupaten Bandar Lampung. Secara geografis, desa ini merupakan daerah pinggiran kota. peneliti melakukan pengamatan tentang peserta didik yang melakukan perilaku agresif. Kelas VIII B merupakan kelas yang di sekolah ini yang dikenal dengan anak- anaknya yang memiliki 
perilaku agresif paling banyak. kelas ini terdiri dari 18 peserta didik laki-laki dan 19 peserta didik perempuan.

Berdasarkan hasil pengamatan peneliti terhadap kelas VIII B, terdapat peserta didik khususnya anak-anak kelas VIII B yang berjenis kelamin laki-laki yang memiliki sikap agresif. Dengan melakukan agresif fisik yaitu, berkelahi memukul, merampas barang milik orang lain, dan menyerang orang lain. Sedangkan secara verbal seperti berteriak-teriak dan ribut di kelas. memaki, mengejek dan melawan terhadap guru. Pada saat itu peneliti melihat perilaku agresif tersebut bahwa setiap hari anak laki-laki bermain di sekolah, kecenderungan permainan berakhir dengan adanya perkelahian, akibat kajadian ini orang tua dari masing-masing peserta didik berseteru di ruang BK. Selain itu saat pelajaran pun sebagian besar anak laki-laki memilih ribut sendiri di kelas dan menjahili teman, merampas hak milik orang lain tanpa izin, mengganggu teman yang sedang fokus belajar, merusak perlengkapan sekolah dan sulit diatur sehingga melawan terhadap guru pada saat jam pelajaran. menurut peneliti kelas VIII B hampir semuanya menunjukan perilaku agresif baik itu agresif fisik dan agresif verbal.

Bandura dan koleganya telah melakukan penelitian secara meluas tentang betapa berpengaruhnya model itu terhadap agresivitas, peranan gender dan standar moral anak. Dalam studi klasik, bandura dan ross, menemukan bahwa onservasi anak terhadap para bintang film (model yang memerankan kekersan) dapat mempengaruhi perkembangan tingkah laku agresifnya. Menurut Corey, konseling behavioral (tingkah laku) berbeda dengan pendekatan pendekatan konseling lainya, ditandai oleh:

1. pemusatan perhatian pada bentuk perilaku yang tampak dan spesifik.

2. kecermatan dan penguraian tujuan treatment

3. perumusan prosedur treatment yang spesifik sesuai dengan masalah

4. penafsiran objektif terhadap hasil terapi. (Aqib, 2013)

Konsep dasar teori Behavioristik yang dikembangkan oleh Skiner \& Ziegler, pandangan tentang manusia:

1. menyatakan bahwa manusian, bahawa perilaku manusia pada dasarnya sangat tergantung pada faktor internal seperti sifatdan lain - lain dan bahwa perilakuyang dimiliki manusia adalah sebagai hasil dari pengkondisian lingkungan dimana manusia berada; dan

2. manusia sehat / menyimpang tidak ada batasan yang jelas mengenai pribadi yang sehat atau tidak sehat. (Aqib, 2013)

Beralih dari salah satu teori Albert Bandura dengan teori belajar sosial, terdapat pula teori behavior modeling yang berakar dari teori belajar sosial yang telah dimulai pada tahun 50-an. Teori Behavior modeling merupakan belajar melalui observasi dengan menambahkan atau menurangi tingkah laku yang teramati, menggeneralisir berbagai pengamatan sekaligus melibatkan proses kognitif. Terdapat beberapa tipe modeling, yaitu: modeling tingkah laku baru yang dilakukan yang melalui observasi terhadap model tingkah laku yang diterima secara sosial, dan individu memperoleh tingkah laku baru. (Dra. Gantina komalasari, 2011)

Penokohan (Modeling) adalah istilah yang menunjukan terjadinya proses belajar melalui pengamatan (observational learning) terhadap orang lain dan perubahan terjadi melalui peniruan. Peniruan (imitation) menunjukan bahwa perilaku orang lain yang diamati. Proses belajar melalui pengamatan menunjukan terjadinya proses belajar setelah mengamati perilaku pada orang lain. (Dra. Gantina komalasari, 2011) Terdapat beberapa macam-macam modeling yaitu:

a. Penokohan nyata (live model) seperti: terapis, guru anggota yang di kagumi oleh keluarganya dijadikan model oleh konseli;

b. Penokohan simbolik (symbolic modeling) seperti: tokoh yang di lihat melalui film, vedeo atau media lain; dan 
c. Penokohan ganda (multiple model) seperti: terjadi dalam kelompok seorang anggota mengubah sikap dan mempelajari sikap setelah mengamati anggota lain bersikap. (Dra. Gantina komalasari, 2011)

Modeling merupakan belajar melalui observasi dengan menambahkan atau mengurangi tingkah laku yang teramat, menggeneralisasikan berbagai pengamtan sekaligus, melibatkan proses kognitif. Terdapat beberapa tipe modeling yaitu: Menurut Rochayatun Dwi Astuti, ada tiga tipe-tipe modeling yaitu:

1. modeling tingkah laku baru yang dilakukan melalui observasi terhadap tingkah laku yang diterima secara sosial individu memperoleh tingkah laku baru. Modeling mengubah tingkah laku lama yaitu dengan meniru tingkah laku model yang tidak diterima sosial akan tingkah model itu diganjar atau dihukum;

2. modeling simbolik yaitu modeling melalui film dan televisi yang menyajikan contoh tingkah laku, berpotensi sebagi sumber model tingkah laku; dan

3. model kondisioning banyak yang dipakai Untuk mempelajari respon emosional yang mendapat penguatan Muncul respon emosional yang sama dan ditujukan ke obyek yang ada didekatnya saat ia mengamati model. (Rochayatun, 2015)

Adapun pelaksanaan teknik modeling dalam menangani perilaku agresif

a. tahap pertama, sebuah perencananan tindakan pencatatan data pribadi peserta didiik secara terperinci, sperti menanyakan nama lengkap, alamat tempat tingal orang tua;

b. tahap kedua, diagnosa tau metode yang dilakukkan oleh konselor untuk mengetahui permaslahan yang dihadapi pada peserta didik secara pribadi, kelompok dalam penentuan penyebab permaslahan yang terkait dengan perilaku agresif, Suatu proses menganalisis penyebab suatu masalah yang dihadapi perilku peserta diidk;

b. prognosa langkah-langkah yang akan dilakukan untuk melatih yang akan dilakukakan untuk melatih peserta didik dalam penyelesaian permasalahan yang dihadapi;

c. konseling atau treament adalah proses prosedur penerapan yang telah ditetapkan dalam prognosa.; dan evaluasi melakukan tahap penilaian aspek-aspek atau indikatoryang tercantum pada prognosa yang sudah ditentuakn. Melaui evaluasi ini dapat menetahui bagaimana tingkah laku siswa telah diberi tindakan.

Tahap selanjutnya, refleksi adalah mengingat dan merenungkan kembali suatu tindaka yang seperti dicatat dan diobservasi hasil evaluasi tersebut akan ditindak lanjuti untuk mennetukan rancangan yang akan diberikan atau diterapkan selanjutnya. Sedangkan Rosjidan dalam Gantina menyatakan konseling behavior memiliki empat tahap yaitu: melakukan asesmen (assemen), menentukan tujuan (goal- setting), mengimplementasikan teknik (technique-implementation), evaluasi dan mengakhiri konseling (evaluation termination). Melakukan asessmen (assessment) Tahap ini bertujuan untuk menentukan apa yang dilakukan oleh peserta didik saat ini. Asesmen dilakukan aktivitas nyata, perasaan dan pikiran peserta didik Kafter dalam gantina "mengatakan terdapat tujuh informasi yang digali dalam asesmen yaitu:

a. Analisis tingkah laku bermasalah yang dialami peserta didik saat ini. tingkah laku yang dianalisis adalah tingkah laku khusus;

b. Analisis situasi yang didalamnya masalah peserta didik terjadi. Analisis ini mencoba untuk mengidentifikasi peristiwa yang mengawali tingkah laku dan mengikutinya (anteceden dan consequence) sehubungan dengan masalah peserta didik;

b. Analisis motivasional;

c. d. Analisis self control, yaitu tingkatan kontrol dari peserta didik terhadap tingkah laku bermasalah ditelusuri atas dasar bagaimana kontrol itu dilatih dan dsar kejadian-kejadian yang menentukan keberhasilan self control; 
d. Analisis hubungan sosial, yaitu orang lain yang dekat dengan kehidupan peserta didik diidentifikasi juga hubunganya orang tersebut dengan peserta didik; dan

e. Analsis lingkungan fisik-sosial budaya".

(Dra.Gantina komalasari, 2011)

Dalam kegiatan asesmen konselor melakukan analisis ABC teknik modeling Langkahlangkah pelaksanaan konseling behavioral dengan teknik modeling adalah sebagai berikut: Membuat analisis ABC, yaitu

a. $\mathrm{A}=$ Antecedent , pencetus perilaku (apa penyebab peserta didik tersebut melakukan perilaku agresif disekolah, misalnya, berkelahi, memukul, meyerang dan melawan)

b. $\mathrm{B}=$ perilaku yang dipermasalahkan ( peserta didik yang melakukan perilaku agresif secrara fisik dan verbal disekolah )

b. $\mathrm{C}=$ consequence, akibat (peserta didik akan dipanggil keruangan bimbingan konseling dan akan ditangani oleh guru bimbingan konseling dan akan diberi sanksi). (Dra.Gantina komalasari, 2011)

Menetapka tujuan (goal setting), guru bimbingan konseling dan peserta didik menentukan tujuan konseling sesuai dengan kesepakatan bersama berdasarkan informasi yang telah disusun dan dianalisis. Burks, et dalam Gantina mengemukakan bahwa " fase goal setting disusun atas tiga langkah yaitu: (a) membantu peserta didik untuk memandang masalahnya atas dasar tujuan- tujuan yang diinginkan; (b) memperhatikan tujuan peserta didik berdasarkan kemungkinan hambatan-hambatan situasional tujuan belajar yang dapat diterima dan dapat diukur; (c) memecahkan tujuan ke dalam tujuan dan menyusun tujuan menjadi susunan yang beruntutan". (Dra.Gantina komalasari, 2011)

Implementasi teknik (technique implementation), Setelah tujuan dirumuskan, guru bimbningan konseling dan peserta didik menentukan strategi yang terbaik untuk membantu peserta didik untuk mencapai perubahan tingkah laku yang diinginkan . guru bimbingan konseling dan peserta didik mengimplementasikan teknik- teknik konseling sesuai dengan masalah yang dialami oleh peserta didik.

Evaluasi dan pengakhiran (evaluation-termination) Evaluasi konseling behavioral merupakan proses yang berkesinambungan. Evaluasi dibuat atas dasar apa yang peserta didik perbuat. Tingkah laku peserta didik digunakan sebagai dasar untuk mengevaluasi efektifitas guru bimbingan konseling dan efektivitas tertentu dari teknik yang digunakan. terminasi meliputi: (a) menguji apa yang peserta didik lakukan terkhir; (b) ekplorasi kemungkinan kebutuhan konseling tambahan;(c) membantu peserta didik mentransfer apa yang dipelajari dalam konseling tingkah laku peserta didik; dan (d) memberi jalan untuk memantau secara terus menerus tingkah laku peserta didik. (Dra. Gantina komalasari, 2011)

\section{Metode Penelitian}

Metode penelitian yang digunakan adalah kuantitatif dengan metode design one group pretes-postes. Dengan fokus pada satu kelompok eksperimen dengan memperhatikan sebelum dan sesudah proses konseling behavior dengan teknik modeling, maka akan mendapatkan hasil gambaran yang komprehensif.

\section{Hasil dan Pembahasan}

Penelitian ini dilaksanakan di SMP Negeri 7 Bandar Lampung Tahun Pelajaran 20162017 pada bulan September 2016. Hasil penelitian diperoleh melalui penyebaran instrumen yang bertujuan untuk memperoleh data mengenai gambaran perilaku agresif peserta didik dan 
sekaligus sebagai dasar penyesuaian isi layanan konseling behavioral dengan teknik modeling untuk mengatasi perilaku agresif peserta didik. Hasil penyebaran instrument dijadikan analisis awal untuk perumusan layanan konseling behavioral dengan teknik modeling terhadap peserta didik yang kemudian diuji cobakan guna memperoleh keefektifan.

Penelitian ini bertujuan untuk menurunkan perilaku agresif peserta didik di SMP Negeri 7 Bandar Lampung, perilaku agresif yang memiliki kategori tinggi akan menggangu peserta didik di sekolah. Peneliti dalam menangani permasalahan yang terjadi menggunakan layanan konseling behavioral dengan teknik modeling. Dalam pelaksanaan layanan konseling behavioral peneliti menggunakan beberapa sampel peserta didik kelas VIII dan peserta didik mengikuti konseling behavioral tersebut. Pengambilan sampel ini berdasarkan hasil angket yang diberikan kepada peserta didik, dari hasil angket perilaku agresif yang diberikan kepada 37 peserta didik terdapat 0 peserta didik yang memiliki perilaku agresif yang sangat tinggi, 10 peserta didik yang memiliki perilaku agresif yang tinggi, 25 peserta didik yang memilki perilaku agresif yang sedang, 2 peserta didik yang memilki perilaku agresif rendah, dan 0 peserta didik kategori sangat rendah. Adapun hasil penyebaran angket dapat dilihat pada tabel berikut:

\begin{tabular}{|l|l|r|r|}
\hline Kategori & $\begin{array}{l}\text { Rentang } \\
\text { skor }\end{array}$ & $\sum$ & presentase \\
\hline Sangat tinggi & $125-105$ & 0 & $0 \%$ \\
\hline Tinggi & $105-85$ & 10 & $27,02 \%$ \\
\hline Sedang & $85-65$ & 25 & $67,56 \%$ \\
\hline Rendah & $65-45$ & 2 & $5,40 \%$ \\
\hline Sangat rendah & $45-25$ & 0 & $0 \%$ \\
\hline Jumlah & & 37 & $100 \%$ \\
\hline
\end{tabular}

Berdasarkan tabel berikut terlihat bahwa perilaku agresif peserta didik tergolong tinggi, sehingga peneliti akan memberikan layanan untuk membantu mengatasi perilaku agresif peserta didik. layanan yang akan diberikan yaitu layanan konseling behavioral dengan teknik modeling. Selanjutnya gambaran perilaku agresif peserta didik dapat terlihat dari setiap indikator yaitu (1) perilaku agresif fisik; dan (2) perilaku agresif verbal. Hasil penelitian peserta didik kelas VIII SMPN 7 Bandar Lampung dideskripsikan sebagai berikut: Berdasarkan hasil penelitian menunjukkan gambaran perilaku agresif fisik peserta didik berada pada kategori sangat tinggi sebanyak 1 peserta didik, pada kategori tinggi sebanyak 4 peserta didik, pada kategori sedang sebanyak 29 peserta didik, pada kategori rendah sebanyak 3 peserta didik, dan 0 peserta didik dalam kategori sangat rendah. Secara rinci dapat dilihat pada tabel berikut:

\begin{tabular}{|l|l|r|r|}
\hline \multicolumn{1}{|c|}{ Kategori } & Interval & \multicolumn{1}{c|}{$\sum_{1}$} & presentase \\
\hline Sangat tinggi & $71,4-$ & 1 & $2,70 \%$ \\
\hline Tinggi & $57,8-$ & 4 & $10,81 \%$ \\
\hline Sedang & $44,2-$ & 29 & $78,31 \%$ \\
\hline Rendah & $30,6-$ & 3 & $8,10 \%$ \\
\hline Sangat rendah & $17-$ & 0 & $0 \%$ \\
\hline
\end{tabular}




\begin{tabular}{|l|c|r|}
\hline Jumlah & 37 & $100 \%$ \\
\hline \multicolumn{3}{|c|}{ Gambaran Indikator Perilaku Agresif Fisik }
\end{tabular}

Berdasarkan tabel presentase indikator perilaku agresif verbal peserta didik kelas VIII SMPN 7 Bandar Lampung tergolong kategori tinggi dan sangat tinggi. Hal itu dapat ditandai dengan perilaku agresif peserta didik.

Efektivitas layanan konseling kelompok dengan pendektan behavioral dengan teknk modeling untuk mengatasi perilaku agresif peserta didik dapat dilihat dari perbandingan hasil prettest (sebelum diberikan layanan) dan hasil postest (sesudah pemberian layanan). Sebelum dilakukan perbandingan hasil pretest dan posttest, terlebih dahulu dilakukan uji t untuk mengetahui efektivitas konseling kelompok pendektan behavioral dengan teknik modeling untuk mengatasi perilaku agresif peserta didik.

Hipotesis yang diajukan dalam penelitian ini adalah:

Ha: adanya efektivitas konseling behavioral dengan teknik modeling untuk mengatasi perilaku agresif peserta didik kelas VIII SMPN 7 bandar lampung tahun pelajaran 2016-2017

Ho: tidak ada efektivitas konseling behavioral dengan teknik modeling untuk mengatasi perilaku agresif peserta didik kelas VIII SMPN 7 bandar lampung tahun pelajaran 20162017

Ho $: \mu 1=\mu 0$

Нa $: \mu 1 \neq \mu 0$

Berdasarkan hasil uji t paired sampel test pada layanan konseling kelompok pendekatan behavioral dengan teknik modeling untuk mengatasi perilaku agresif, perhitungan perilaku agresif peserta didik dilakukan dengan menggunakan SPSS for windows reliase 17, dapat dilihat dari hasil tabel berikut

\begin{tabular}{|l|l|l|l|l|l|l|l|}
\hline Hasil & Rata-rata & Sd & Perbedaan rata-rata & Statistik uii t & Sig & Sig.2 tailed & Keterangan \\
\hline Prettest & 73,3000 & 5,49848 & 4,40568 & 4,063 & 0,594 & 0,003 & Signifikan \\
\hline Posttest & 55,4000 & 11,78700 & & & & & \\
\hline
\end{tabular}

Dari hasil tabel 4.5 tersebut dapat rata-rata posttest adalah 55,4000 dan rata-rata prettest adalah73, 3000 .hasil perhitungan pengujian diperoleh thitung 4,063 pada derajad kebebasan (df) 9 kemudian dibandingakan dengan ttabel 0,05 =2,262 kemudian dibandingkan dengan ttabel ketentuan thitung lebih dari tabel $(4,063 \geq 2,262)$. ini menunjukan bahwa Ho ditolak dan Ha diterima, selain itu dapat nilai rata-rata prettest lebih besar dari posttest $(73,3000 \geq$ 55,4000). Jika dilihat dari nilai rata-rata maka penurunan perilaku agresif peserta didik setelah diberikan layanan lebih rendah dibandingkan sebelum diberikan layanan. menunjukan rata-rata penurunan perilaku agresif sebelum dan sesudah diberikan layanan. Hasil uji statistik efektivitas konseling behavioral dengan teknik modeling untuk mengatasi perilaku agresif pada indikator perilaku agresif fisik diperoleh hasil sebagai berikut:

\begin{tabular}{|l|l|l|l|l|l|l|l|}
\hline Hasil & Rata-rata & Sd & Perbedaan rata- & Statistik uji tSig & Sig.2 & Ket \\
\hline Prettest & 48,9000 & 5,56677 & 31,15331 & 3,203 & 0,417 & 0,011 & Signifika \\
\hline Posttest & 38,8000 & 10, & & & & & \\
\hline
\end{tabular}

Berdasarkan tabel terlihat pada indikator perilaku agresif fisik hasil uji t paired prettest dan posttest adalah signifikan karena memiliki nilai sig. 2 tailed $\leq 0,05 \quad(0,011 \leq 0,05$. hal ini menunjukan bahwa terdapat perbedaan penurunan perilaku agresif indikator antara prettest dan posttest. Jika dilihat dari rata-rata maka penurunan indikator perilaku agresif fisik pada posttest lebih rendah dibandingkan prettest. 
Pembahasan penelitian diawali dengan profil perilaku agresif dilanjutkan dengan menganalisis layanan konseling kelompok. Adapun pembahasan kefektifan layanan konseling kelompok pendekatan behavioral dengan teknik modeling untuk mengatasi perilaku agresif peserta didik adalah sebagai berikut: Berdasarkan hasil prettest yang telah dilakukan menunjukan bahwa perilaku agresif peserta didik rata-rata berada pada kategori tinggi dan sedang. Apabila dibiarkan akan mempengaruhi kegiatan belajar peserta didik disekolah. Karena peserta didik yang memiliki perilaku agresif akan mengalami frustasi atau perilaku yang merugikan diri sendiri maupun orang lain. Selanjutnya situasi frustasi akan membuat orang marah dan akan memperbesar kemungkinan mereka melakukan perilaku agresif, hal ini selaras dengan pendapat Baron dan Byrne, salah satu ciri khusus orang yang mempunyai perilaku agresif adalah manusia yang tidak berbeda jauh dengan hewa, sebagaimana organisme lainya mekanisme tingkah laku manusia dianggap sama dengan tingkah laku hewan. Dalam hal ini perilaku agresif dipandang sangat mempengaruhi peserta didik terutama di masa perkembangan yang dilaluinya terutama usia remaja. Hal ini jelas bahwa untuk membentuk pribadi yang mandiri dan bertanggung jawab serta mengoptimalkan potensi yang ada pada diri peserta didik yang duduk di bangku sekolah menengah pertama ini.

Kondisi perilaku agresif dalam peserta didik kelas VIII di SMPN 7 bandar lampung berdasarkan presebtase urutan indikator perilaku agresif sebagai berikut; (1) perilaku agresif fisik; dan (2) perilaku agresif verbal. Berdasarkan hasil tersebut maka peneliti menggunakan layanan konseling kelompok pada dasarnya adalah layanan konseling perorangan yang dilaksanakn didalam suasana kelompok. Pada pelaksanaan konseling kelompok yang terjadi hubungan yang hangat, permisif, terbuka dan penuh keakraban. Selain itu juga ada pengungkapan dan pemahaman masalah peserta didik, penelusuran sebab-sebab timbulnya masalah, uapaya pemecahan masalah, kegiatan evaluasi dan tindak lanjut. Didalam konseling kelompok terdapat dinamika interaksi sosial yang dapat berkembang dengan intensif dalam suasan kelompok. Melalui dinamika interaksi sosial yang terjadi antar anggota kelompok, masalah yangdialami oleh masing-masing individu akan dienteskan. Dinamika interaksi sosial yang secara intensif terjadi dalam suasana kelompok dengan pendekatan behavioral dapat menurunkan perilaku agresif dengan modifikasi perilaku sebagai tindakan yang bertujuan untuk mengubah perilaku . modifikasi perilaku daat sebagai usaha menerapakan prinsip-prinsip belajar hasil pada perilaku manusia. Pada pelaksanaan layanan konseling kelompok dnegan pendekatan behavioral dengan teknik modeling. Pendekatan behavioral adalah suatu treatment atau suatu pemberian bantuan kepada seseorang guna membantu seseorang tersebut untuk mengubah perilaku yang maladaftif menjadi adaptif dengan menggunakan teknik modeling. Ini berarti kebiaasaan- kebiasaan yang malafdatif dilemahkan dan dihilangkan, kemudian perilaku adaftif ditimbulkan dan dikukuhkan. Modeling adalah istilah yang menunjukan terjadinya proses belajar melalui pengamatan terhadaporang lain dan perubahan terjadi melalui peniruan. Peniruan menunjukan bahwa perilaku orang lain yang diamati. Proses belajar melalui pegamatan menunjukan terjadin ya proses belajar setelah mengamati perilaku pada orang lain, yaitu dengan penokohan nyata (live model) dengan mengubah tingkah laku lama dengan tingkah laku baru dengan meniru tingkah laku model.

Berdasarkan analisis data yang menunjukan adanya perbedaan perilaku agresif peserta didik setelah dilaksanakan layanna konseling kelompok pendekatan behavioral dengan teknik modeling. Hasil penelitian menunjukan bahwa rata-rata perilaku agresif peserta didik setelah dilaksanakan layanna konseling kelompok pendekatan behavioral dengan teknik modeling menjadi lebih baik dari kriteria tinggi menjadi rendah, adapun penurunan perilaku agresif pesertsa didik dapat diliahat pada indikator berikut ini:

Berdasarkan hasil data penelitian bahwa pada indikator perilaku agresif fisik mengalami penurunan, terlihat pada presentase pada waktu prettest lebih kecil pada saat posttest. Penurunan perilaku agresif peserta didik pada indikator ini dapat diliahat perilaku 
peserta didik mulai memilki kemauan dan usaha untuk bertanya kepada teman ataupun gurunya jika merasa kurang paham dengan pelajaran serta yakin dengan kemampuan yang dimilikinya . hal ini sesuai dengan pendapat Baron dan Byrne, salah satu ciri khusus orang yang mempunyai perilaku agresif adalah manusia yang tidak berbeda jauh dengan hewan, sebagaimana organisme lainya mekanisme tingkah laku manusia dianggap sama dengan tingkah laku hewan.

Berdasarkan hasil data penelitian bahwa pada indikator perilaku agresif verbal mengalami penurunan, terlihat pada presentase pada waktu prettest lebih kecil posttest . penurunan perilaku agresif verbal peserta didik pada indikator ini dapat dilihat dari perilaku agresif peserta didik mulai berubah yang biasanya didalam kelas melakukan keributan dikelas dan memaki- maki, mengejek teman satu bangkunya dengan cara di sengaja kini sekarang mulai berubah pada saat kegiatan belajar di kelas. Hal ini sesuai dengan pendapat fuad nashori bahwa orang yang sering marah akibat dari serangan atau gangguan orang lain Berdasarkan hasil kegiatan layanan bahwa perilaku agresif pada peserta didik menurun dari sebelumnya, hal ini membuktikan bahwa layanan konseling kelompok pendekatan behavioral dengan teknik modeling efektif untuk mengatasi perilaku agresif. Layanan konseling kelompok banyak bermanfaat yaitu dapat menambah wawasan, mengakrabkan satu dengan yang lainy, dan dapat melatih keberanian untuk berbicara. Tujuan dari penelitian ini membantu peserta didik dalam menurunkan perilaku agresif dalam layanan yang dilakukan dapat di jadikan sebagai tempat bertukar ide, pendapat, gagasan, serta pengalaman.

Tercapainya tujuan penelitian mulai terlihat dimana peserta didik sangat berantusias dalam proses pemebrian layanan. Peserta didik antusias dalam mengungkapkan ide dan gagasannya, adanya interaksi yang baik antara pemimpin kelompok dan peserta didik sehingga peserta didik saling meberikan pendapat dan saran ketika kegiatan berlangsung. Dan ketika kegiatan akan berakhir peserta didik saling bergantian untuk menyimpulkan pemahaman materi yang akan dibahas.

\section{Simpulan dan Saran}

Berdasarkan hasil analisis data perhitungan rata-rata skor perilaku agresif sebelum mengikuti layanan konseling kelompok adalah tinggi dan setelah mengikuti layanan konseling kelompok pendekatan behavioral dengan teknik modeling menurunn menjadi rendah. Dari hasil uji t menggunakan program SPSS versi 17 dapat diketahui bahwa dapat rata-rata posttest adalah 47,2 dan rata-rata prettest adalah 73,3. Berdasarkan hasil perhitungan pengujian diperoleh thitung 4,063 pada derajad kebebasab (df) 9 kemudian dibandingkan dengan tabel 0,05=2,262, ketentuan thitung lebih besar dari ttabel $(4,063 \geq 2,262)$. Ini menunjukan bahwa Ho ditolak dan Ha diterima, selain itu dapat nilai rata- rata, maka penurunan perilaku agresif peserta didik setelah diberikan layanan lebih rendah dibandingkan sebelum diberikan layanan. Dengan demikian perilaku agresif peserta didik terdapat perubahan setelah diberikan layanan konseling kelompok pendekatan behavioral dengan teknik modeling. Maka dapat disimpulkan bahwa terdapat efektivitas layanan konseling kelompok pendekatan behavioral dengan teknik modeling dalam penurunan perilaku agresif peserta didik kelas VIII SMP Negeri 7 bandar lampung tahun pelajaran 2016/2017.

\section{Daftar Pustaka}

Aqib Zainal, 2012. Bimbingan Dan Konseling Di Sekolah,Bandung: Yrama Widya

Arikunto Suharsimi, 1985.Prosedur Penelitian : Suatu Pendekatan Praktek, Jakarta: Rineka Cipta.

Bimo Walgito, 2003. Psikologi Sosial, Yogyakarta: C.V Andi. 
Kadek Wilandatika Pigura,"Penerapan Konseling Behavioral Dengan Teknik Modeling Untuk Menimilisir perilaku agresif siswa kelas XI bahasa SMA Negeri 2 Singaraja".(Skripsi Bimbingan Konseling Universitas pendidikan Ganesha Singaraja, Singaraja.

Indriyati Laili, 2007.Keefektifan Pendekatan Konseling Behavioristik dengan Teknik Bermain Peran untuk Mengurangi Perilaku Agresif pada Siswa Kelas XI SMA Purusatama Semarang Tahun 2006/2007.(Skripsi. Jurusan Bimbingan dan Konseling Fakultas Ilmu Pendidikan Universitas Negeri Semarang.

Komalasari Gantina, dkk 2011. Teori dan teknik konseling, jakarta: indeks.

Kursin, 2004/2005. keefektifan layanan konseling kelompok dalam mengurangi perilaku agresif siswa panti pamardi putra mandiri semarang, skripsi, jurusan bimbingan dan konseling FIP.UNNES.

Muslimah Azizah, D. 2013. Mengurangi Perilaku Agresif Melalui Layanan Klasikal Menggunakan Teknik Sosiodrama. Tegal, (Skripsi Program Studi Bimbingan Konseling Jurusan Ilmu Pendidikan UNS.

Nashori Fuad, 2008. Psikologi Sosial Islami, Bandung: PT Refika aditama.

Prayitno, 2008.Dasar-Dasar Bimbingan dan Konseling, Jakarta: Rineka Cipta.

Nashori Fuad, 2008. Psikologi Sosial Islami,Bandung: PT Refika aditama,

Rochayatun D. A, 2015. “ Teknik Modeling Dalam Bimbingan Kelompok Untuk Meningkatkan Kemandirian Belajar Siswa SMAN 3 Yogyakarta”. (skripsi fakultas dakwah dan komunikasi, Universitas Islam Negeri Sunan Kalijaga,Yogyakarta.

Rosita Yuni, 2008. Pelaksanaan Konseling Behavioral dalam Mengatasi Phobia Kucing Seorang Klien Dirasamala 2 Menteng, Jakarta Selatan.( skripsi. Jurusan bimbingan konseling dan penyuluhan Islam Fakultas Dakwah, Jakarta.

Sukardi Dewa Ketut, 2008. Pengantar Pelaksanaan Program Bimbingan dan Konseling di sekolah, Jakarta: Rineka cipta.

Sugiyono, 2011. Metode Penelitian Kuantitatif Kualitatif dan R\&D, Bandung: Alfa Beta

Syamsu Yusuf \& Juntika Nurikhsan, 2013. Teori Kepribadian, Bandung: PT.Remaja Rosdakarya.

Sarlito, W. S. Eko. A. M. 2009. Psikologi Sosial. Jakarta : Salemba Humanika.

Shelley e. Taylor. Dkk, 2009. Psikologi Sosial, Jakarta: Kencana.

Sukardi, 2009 Metodologi Penelitian Pendidikan Kompetensi dan Praktiknya, Jakarta: PT Bumi Aksara

Thrisia Febrianti, 2014. "Pengaruh Layanan Konseling Kelompok Terhadap Perilaku Agresif siswa kelas VII di SMPN 3 kota Bengkulu”. ( Skripsi Program Studi Bimbingandan Konseling Universitas Bengkulu, bengkulu. 
